\title{
Automation in College Libraries
}

\section{Richard Hume Werking}

This article reports results of a survey of the "Bowdoin List" group of liberal arts college libraries. The survey obtained information about which automation modules were in place at the library and when they had been installed; the financing of automation and the impact on the library's budget; and library directors' views about several matters relating to library automation and the nature of the college library.

lthough library automation is a popular topic in the professional literature, as well as in conversations and conference programs involving academic librarians, little has been done to provide overviews of the state of automation in academic libraries. ${ }^{1}$ This article attempts to provide such an overview, albeit a cursory one, for thirty-five of the forty-two liberal arts college libraries in the "Bowdoin List" group.

A previous article, CERL January 1991 issue, reported on collection growth and shifts in patterns of expenditures in this group of college libraries, comparing the findings with developments in research libraries. As a part of that same research project, I surveyed the college library directors in the winter and spring of 1989 about automation in their libraries. ${ }^{2}$ Readers should consider that the data, attitudes, and opinions reported here for the colleges are as of mid-1989.

\section{COMPONENTS REPORTED OCLC/RLIN}

By 1982 all thirty-five college libraries responding to the survey had implemented the OCLC bibliographic network, with the exception of one that is using RLIN instead. The first of these libraries to adopt OCLC did so in 1967.

\section{TABLE 1: OCLC/RLIN}

$\begin{array}{ll}\text { First } & 1967 \\ \text { Third } & 1972 \\ \text { One-fourth } & 1974 \\ \text { Half } & 1975 \\ \text { Three-fourths } & 1978 \\ \text { Third most recent } & 1980 \\ \text { Most recent } & 1982\end{array}$

Richard Hume Werking is Director of Libraries at Trinity University in San Antonio, Texas 78212 He gratefully acknowledges the many contributions of Dorothy $R$. Williams, his adminstrative assistant at Trinity; financial support from Trinity and the Council on Library Resources; and the cooperation and interest of the "Bowdoin List" college library directors in the preparation of this study and the one published in the January 1991 issue of CERL. 


\section{Online Circulation}

In sharp contrast, only thirteen of the thirty-five libraries have acquired an online circulation system. The first of these was added in 1979, and the most recent in 1989 , but only two before 1987 . The table below demonstrates the recency of this adoption.

\begin{tabular}{lr}
\multicolumn{2}{c}{ TABLE 2: ONLINE } \\
\multicolumn{2}{c}{ CIRCULATION SYSTEMS } \\
First & 1979 \\
Second & 1986 \\
Third \& Fourth & 1987 \\
Fifth through eighth & 1988 \\
Ninth through thirteenth & 1989
\end{tabular}

On the other hand, by 1987 three-quarters of the 115 research libraries responding to the ARL Automation Inventory of that year (74 percent) had installed an automated circulation system. ${ }^{3}$

\section{Online Acquisitions}

A greater number of the college libraries, fifteen of them, have implemented an online acquisitions system, beginning in 1981. More than half of these libraries have acquired such systems during the past two years, as the following distribution shows.

TABLE 3: ONLINE ACQUISITIONS SYSTEMS

\begin{tabular}{cc}
\hline $\begin{array}{c}\text { Number of } \\
\text { Libraries }\end{array}$ & $\begin{array}{c}\text { Year } \\
\text { Acquired }\end{array}$ \\
\hline 2 & 1981 \\
2 & 1982 \\
2 & 1984 \\
1 & 1987 \\
6 & 1988 \\
2 & 1989
\end{tabular}

By 1987,74 percent of the ARL libraries had implemented automated acquisitions systems, exactly the same percentage as for circulation. ${ }^{4}$

\section{Online Serials}

Only ten of these college libraries own online serials systems-fewer than any other automated component-with the first one implemented in 1982 and the most recent in 1989, and only half of them implemented by 1988 . Likewise, in 1987 fewer than half the ARL libraries, 42 percent, had online serials systems. ${ }^{5}$

\section{Online Public Catalog}

In marked contrast, twenty-one of the thirty-five college libraries (60 percent) have online public catalogs, eighteen of them acquired in the last three years and the first acquired as recently as 1983 .

\section{TABLE 4: ONLINE PUBLIC CATALOGS}

\begin{tabular}{cc}
\hline $\begin{array}{c}\text { Number of } \\
\text { Libraries }\end{array}$ & $\begin{array}{c}\text { Year } \\
\text { Acquired }\end{array}$ \\
\hline 1 & 1983 \\
1 & 1985 \\
1 & 1986 \\
5 & 1987 \\
7 & 1988 \\
6 & 1989
\end{tabular}

The directors at an additional thirteen of the thirty-five libraries expect to have an online catalog in operation within two to three years, and the other director expects one in three to five years. In 1987, seventy-one percent of the ARL libraries reported that they had installed online catalogs, compared with fewer than onequarter of the responding college libraries. ${ }^{6}$

\section{CD/ROM Technology}

Twenty-six of the thirty-five responding college libraries presently have CD/ROM technology, the first of which was acquired as recently as 1986 . The number of $\mathrm{CD} / \mathrm{ROM}$ products ranges from one to seven per library.

\section{FINANCING AUTOMATION}

\section{Financing Initial Costs}

The college library directors were presented with a list of methods and asked: 
"How has your library financed, or how do you expect it to finance, the initial cost of the [above] technologies?" The thirtyfive respondents selected a total of 103 methods. The methods are indicated in descending order of occurrence in the table below.

\section{TABLE 5:}

\section{FINANCING INITIAL COSTS}

\begin{tabular}{lc}
\hline Method & $\begin{array}{r}\text { Times } \\
\text { chosen }\end{array}$ \\
\hline $\begin{array}{l}\text { Special one-time allocations from } \\
\text { college or university } \\
\text { administration }\end{array}$ & 26 \\
\hline
\end{tabular}

Special grants from private foundations

Operating funds [chiefly for OCLC and CD/ROM]

Special gifts or bequests from benefactors

Special government grants

As part of a building fund

Through cooperative purchasing

Other:"as part of college capital campaign"

Other:"fabulous discount...by vendor"

It is worth noting that the one option offered that was not chosen by any of the thirty-five respondents was "special user fees/charges," a method some university libraries have used to finance integrated online automation systems.)

\section{Ongoing Costs}

Directors were also asked: "How is your library financing, or how do you expect it to finance, the ongoing costs of these technologies?" Thirty-four directors identified fifty-six methods. (See table 6.)

\section{Extent of Impact on Existing Library Budget}

The college library directors were asked: "To what extent have the costs of automation been borne from within the library's budget, either from funds already in the budget or from funds that would otherwise have gone elsewhere
TABLE 6: METHODS/FINANCING ONGOING COSTS

\begin{tabular}{lc}
\hline Method & $\begin{array}{c}\text { Times } \\
\text { chosen }\end{array}$ \\
\hline $\begin{array}{l}\text { Operating funds } \\
\text { Special grants from private }\end{array}$ & 33 \\
foundations & 6 \\
$\begin{array}{l}\text { Special gifts or bequests from } \\
\text { benefactors }\end{array}$ & 5 \\
$\begin{array}{l}\text { Through cooperative purchasing } \\
\text { Special government grants }\end{array}$ & 4 \\
$\begin{array}{l}\text { Special one-time allocations from } \\
\text { college or university administration }\end{array}$ & 3 \\
$\begin{array}{l}\text { Other:"discount" } \\
\text { oth }\end{array}$ & 1
\end{tabular}

within the library budget?" The responses, and the number of directors choosing them, are provided below. Thirty-three usable responses were received.

\section{TABLE 7: AUTOMATION FINANCED THROUGH THE LIBRARY'S BUDGET}

\begin{tabular}{lc}
\hline Response & Number \\
\hline "Not at all" & 20 \\
"To a limited extent" & 10 \\
"To a great extent" & 3
\end{tabular}

The three directors choosing "a great extent" reported that the total impact was $\$ 39,500, \$ 30,000$, and $\$ 8,767$. Only one of these three libraries, that which reported $\$ 30,000$, has an online public catalog. The library reporting the $\$ 39,500$ figure has recently invested in a number of $\mathrm{CD} / \mathrm{ROM}$ products and workstations. Of the ten directors selecting "a limited extent," nine could provide a specific dollar impact, as follows: $\$ 50-$ $75,000, \quad \$ 50,000, \quad \$ 35,000, \quad \$ 25,000$, $\$ 24,000, \$ 20,000, \$ 6,000, \$ 3,000-5,000$, and $\$ 2,000$. Of these ten libraries, all but two have installed online public catalogs. Of the twenty library directors responding "not at all," eleven of their libraries have online public catalogs; one of these directors, whose library had recently installed an integrated system, added the observation "Thank God!" 


\section{INTERVIEW RESPONSES}

At the twenty-two libraries visited, I learned a great deal about several closely related issues involving the introduction of (what was for them at least) $1980 \mathrm{~s}$ automation: the online public catalog and the other components identified above. These issues were the perceived benefits of automation, the willingness of the directors to reduce acquisitions or staffing levels in order to automate their libraries, perceived trade-offs involving automation, and the directors' perceptions about the changing nature of the college library. Twelve of these libraries already had automated catalogs, one had selected an integrated system, while another four were actively involved in the selection process.

\section{Benefits of Automation}

Twenty-two of the directors responded to the question "What do you consider the benefits of automating?" (This was indicated to be a level of automation beyond OCLC and online database searching.) Listed below are the benefits that were offered by two or more of the respondents, in descending order of occurrence.

- Thirteen of the directors included better searching of the catalog by patrons as an important benefit.

- Six mentioned efficiencies in various clerical operations. One commented, "I'm tired of maintaining a card catalog, thank you," while another observed that "We used to spend tens of thousands of dollars a year for filing cards; we're now using people to better advantage."

- Another six offered the sharing of library resources through consortia as a benefit. As one of them put it, "Networking is the reason for automating, not just the library asking for money to fancy up its card catalog."

- Five directors referred to automation's either enabling or facilitating shared acquisitions and shared collection development with certain nearby libraries.
- Five respondents mentioned the possibility of remote searching of the catalog by faculty from their offices, or by others.

- Another five referred to obtaining management information from circulation statistics about which parts of the collection were being used.

Four of the directors brought up the library's image vis-à-vis other libraries and its image on the particular campus. One of them said she occasionally heard comments from students to the effect that "My home town library has an online catalog; why doesn't this one?" Another director observed that the library's position on the campus had been enhanced. A third noted: "The idea that the college has managed to do something of this sort for its students has helped donations from younger donors ( $a$ 'cradle to the grave' view). They identify with the library as an up-and-coming place. We've implanted ourselves in their minds this way; normally we don't hear from them until they're out about twenty-five years."

A separate image issue offered by three directors was that library automation is a factor in admissions competition with other institutions, to gain "a competitive edge in the liberal arts marketplace," as one of them put it. Two respondents in environments with several branch libraries pointed to the advantage of "getting everything into one database." Two more directors were quite interested in the prospect of owning and mounting additional databases. Another two respondents considered library automation an important factor in the library's increasing role in coordinating information on campus.

A benefit explicitly offered by only one director is nonetheless worth repeating. According to him, a very important benefit was the opportunity for weeding the collection: "I'm one librarian who's trying not to build another building."

\section{Acquisitions and Staff Dollars versus Automation Dollars}

During the interviews, I askedthe directors: "Would you reduce acquisitions in order to automate?" Of the twenty- 
one usable responses, eleven were "no," seven were "yes," two were "no initially but yes later," and one director was undecided. While the directors were quite protective of acquisitions dollars, they were even more protective of staff dollars. In response to the question "Would you reduce staff (including student workers), or reduce pay increases in order to automate?" sixteen of the directors said "no," three replied with a highly qualified affirmative, and one did not know.

\section{Trade-offs Involving Automation}

All the directors interviewed thought that the advantages that had been brought or would be brought by the introduction of automation outweighed any disadvantages. At the same time, some of them perceived problems that they were encountering or likely would encounter in their libraries as a result. Some of their observations are given below.

The biggest problem is the online catalog itself and the use of it. Subject searching isn't easy. The user is given so much more than he or she can handle, and the catalog isn't used well. Also, records need to be cleaned up. The headings themselves are problematic, and there are inconsistencies in how our several institutions have treated headings. But I'd rather have these problems than the problems of the card catalog.

Trade-offs with automation other than cost? Well, there's somewhat less attention by reference people to the traditional user, sacrificing the traditional user; we don't give up an online search to help someone at the reference desk because we get instant gratification from the online search process. Also, online searching is more fun. But I don't think things are necessarily being lost.

We have the worst card catalog known to man; at...we had a great card catalog. Automation is forcing us to be disciplined, and it will cost the library some money, maybe $\$ 50,000$ a year in economies: acquisitions, travel budget, maybe staff.
I don't think the college libraries have suffered much, so far, in terms of the costs of introducing automation. The larger campuses have suffered more in that they've had to eat into their own money.

Automation is a costly thing that provides different services. It's hard to compare what you get with what you were getting.

By putting our catalog into a local area network, we may lose contact with the faculty, especially if that is combined with having materials delivered to their offices. Presently, this is how we see the faculty, when they come to the library.

The big thing is the dollar cost, but there's also the political cost. Luckily here the introduction of automation has been tied to a new building, although I did get $\$ 50,000$ more annually for maintenance. God help me if I need to ask for a new reader-printer; I've used up my chips and don't have any for awhile. This is true not just of automation, but would be true for any big expense, like a building. It's like the syndrome among the state legislators in [the state capital]: "We did health last year."

\section{Is the Nature of the College Library Changing Fundamentally?}

The directors were asked, "Is the nature of the college library changing very much, changing fundamentally, at your institution and around the country?" Eight of the directors believed that it was, six believed it was not, and the rest of the responses were mixed.

Not fundamentally. Librarians are more service-oriented, whereas they used to be collection oriented.

Certainly the way we do business is changing. The basis of what libraries do is pretty much the same-provide information. But we don't have to own as much of it, and we have other ways of getting at it.

Not really. Automation and various media introduce a different way of working, but that doesn't matter much; people adapt and come to take 
it for granted. Alumni might find it bewildering and think that we're already in the twenty-first century.

Yes, it is changing fundamentally. It's splitting in half, into two types of libraries. Librarians are still responsible for information services: census tapes, books, sound CDs, slides, scanners, satellite dishes, microforms; and then there is the museum side, the special collections where people are concerned about the book as an artifact, displays, preservation, etc. The biggest change I've noticed in librarianship is the tendency of the administration to want to expand the definition of the library. The language laboratory is now a part of it. There is a whole new set of problems: satellite TV, interactive video, CAI, etc. I worry about how to encourage the faculty and educate them. The satellite dish will place a lot of demands on us for taping programs. Students are wanting to start a new TV station, and work with me and the AV librarian. Unless we expand this way and take on responsibility for additional forms of information, we'll die.

Yes, and I think it's the nature of the college librarian. The most notable change in my professional life is getting librarians out of clerical detail, and into administrative matters, teaching (like bibliographic instruction), and more reference work. When I came to this institution, there wasn't much demand for reference help. There was not even a separate reference desk; the librarians got behind the circulation desk and did more circulation work, as circulation supervisors. Librarians are also taking on a larger role in collection development, which used to be faculty driven.

\section{CONCLUSIONS}

The introduction of online library automation into this group of colleges has lagged behind the same phenomenon in the ARL libraries. Nevertheless, during the 1980 s automation caught on rapidly among this group, to the point where three-fifths of the thirty-five reporting libraries had installed online catalogs, or were to have installed them by the end of 1989. Perhaps in part because of the speed with which automation has taken hold, the associated costs of computer hardware and software, some maintenance, and a good deal of retrospective conversion have generally come from outside the library budget, either from the college administration or from outside the college altogether. In fact, perhaps it is the externality of the funding that may explain some of the rapidity with which automation has been and is being adopted in these college libraries. In contrast, the impression lingers that because of the much greater automation costs in the research libraries and the more formidable task of retrospective conversion, these institutions are more frequently obliged to absorb these costs from the library budget, often by leaving salary lines open. Another factor may be that many of the ARL libraries are in publicly supported universities and hence have received relatively few grants from foundations to support automation.

An important question is the extent to which the college libraries' current budgets will remain relatively immune from the future costs of upgrading and replacing computer hardware and software. Perhaps the percentage of expenditures for materials will begin to decline. Studying the data from the twenty-one libraries that have installed an online catalog, or expected to install one by the end of 1989, gives no indication that the materials budget has yet suffered as a result. The median percentage of expenditures for materials among these libraries, both in 1986-87 and in 1987-88, was thirty-seven, one point below the median for the larger group; and in 1988-89 it had risen to thirty-eight percent. Compared with their own percentages ten years before, in 1976-77, eleven of these libraries had higher percentages in 1986-87, nine had lower, and one showed no change. For 1987-88 ( $\mathrm{N}=20)$, ten of them show a higher percentage than the previous year, eight show a smaller, and for two there was no change. For 1988-89 ( $\mathrm{N}=20)$, seven of these libraries show a higher percentage 
than in 1987-88, seven show a smaller, and six show no change.?

College library directors often see trade-offs involving library automation, but none of them believes that the disadvantages outweigh the advantages. Although the college library directors disagree about how "fundamental" the changes are, they perceive that academic libraries are changing the ways in which they operate. An important question concerns the role of the librarian in the more electronic environment. Many of the directors anticipate a greater degree of librarian involvement with students. To the extent that they are correct, and to the extent that relatively more dollars will go to pay for more librarians, or for higher salaries to attract or retain capable librarians with high degrees of energy and skill, it is quite possible that materials expenditures will decline proportionately. This trend would run exactly counter to the recent plea by Jerry Campbell, university librarian at Duke, that "materials/access" should grow to 50 percent of expenditures and that salaries/wages should drop to 33 percent. In Campbell's opinion, "we simply cannot provide enough people to answer all the questions." ${ }^{8}$ One problem with his construct, however, as with much of the current discussion about "access," is that library staff, like all other elements in the library operation including the collection, are there to provide "access."

\section{REFERENCES AND NOTES}

1. There have been four "automation inventories" produced for members of the Association of Research Libraries between 1984 and 1988, and ARL has produced at least two SPEC kits which furnish some of this information for thirty-one and twelve member libraries, respectively: The Automation Inventory of Research Libraries (Washington, D.C.: Office of Management Services, Association of Research Libraries, 1988); Integrated Library Information Systems in ARL Libraries, SPEC Kit 90 (Washington, D.C.: OMS, Association of Research Libraries, 1983); Automated Library Systems in ARL Libraries, SPEC Kit 126 (Washington, D.C.: OMS, Association of Research Libraries, 1986).

2. Richard Hume Werking, "Collection Growth and Expenditures in Academic Libraries: A Preliminary Inquiry," College \& Research Libraries 51:5-23 (Jan. 1991). This article provides details about my research via questionnaires and interviews. For additional information, including additional responses garnered during my interviews with library directors, and a copy of the survey instrument, see Collection Growth, Expenditures, and Automation in Academic Libraries: A Preliminary Inquiry (Educational Resources Information Center, Document \#318482, 1990).

3. OMS, ARL, Automation Inventory (1987), p.7.

4. Ibid.

5. Ibid., p.8.

6. Ibid., p.7.

7. Data in the possession of the author and described in both publications cited in note 2, above.

8. Jerry D. Campbell, "Academic Library Budgets: Changing 'The Sixty-Forty Split,'" Library Administration \& Management 3:79 (Spring 1989). 


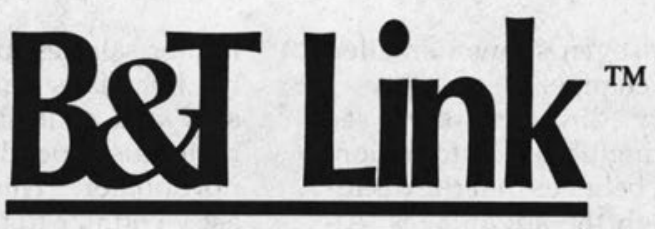

\section{It's now even bigger, faster, and more accurate - connecting you to our 10 million book inventory plus any in-print, out-of-print, and forthcoming title.}

Fill all your book ordering needs in one place in record time thanks to B\&T Link ${ }^{\mathrm{TM}}$ - an extraordinary system of search and order software modules from Baker \& Taylor Books. With more refinements and conveniences than you ever dreamed possible, B\&T Link literally puts any book at your fingertips.

\section{Module 1: Ordering}

Get it smarter, faster, easier. No matter how simple or intricate your ordering method, ordering through B\&T Link gives you lots of new advantages. Our special order feature lets you customize every line item with customer requests, multiple distribution notes, as well as print notification postcards.

Now, in addition to sending orders upon completion, you

can also transmit orders automatically into our mainframe at a convenient predetermined contime. Use our new ordering interfaces to output data in a variety of standard formats to other software products. Or check in shipments with our new on-screen receiving.

And of course, B\&T Link still provides the most comprehensive confirmation report you can get. And it's yours free.

\section{Module 2: Database, The Title Source}

Find any book, in every detail. B\&T Link's new Module 2 bibliographic software on CD-Rom puts you in complete command of over 1.2 million book, video, audio, calendar, in-print, out-of-print and forthcoming titles. You'll enjoy extraordinary accuracy through our system of "linked" ISBN's that automatically takes you to the most recent ISBN. Nine easy ways to search our comprehensive database allow you to quickly create a title listing, including hard-to-find titles. We've even made searching up to $20 \%$ faster.
Database, The Title Source reports on everything from multiple bindings to the latest price and publication status, and is updated every month to include more than 80,000 changes.

\section{Module 3: Inventory}

Take stock at a glance. Using B\&T Link Inventory software is like standing in our warehouse. You'll know immediately what's in stock and what's on order in your regional service center.

You'll get weekly updates on diskettes of an inventory with over 120,000 titles. And that's not all. Soon to be added to the B\&T Link system are Invoicing, Ordering History, Fund Accounting, and Open-to-Buy modules. When it comes to getting a book, B\&T Link is the system that does it with convenience and the any book advantage.

For more information, call

800-233-3657

\section{BAKER \& TAYLOR Books}

